\title{
The Soils of Kiritimati (Christmas) Island, Kiribati, Central Pacific: New Information and Comparison with Previous Studies ${ }^{1}$
}

\author{
R. 7. Morrison ${ }^{2,3}$ and C. D. Woodroffe $e^{3,4}$
}

\begin{abstract}
Kiritimati, the largest land area atoll in the world, is undergoing rapid population increase, and, given the isolation of the island, local food production will have to be expanded to support the residents. Two soils investigations were completed in the $1960 \mathrm{~s}$, but no additional information on the soil resources of the island has been produced since that time. In this study, 15 soil profiles were described and analyzed. Where possible, comparison has been made with previous work, and discussion of the soil-forming factors is presented. Results confirm that soils are weakly developed (Entisols) with relatively low organic matter contents and low water-retention capacity. These properties are expected from the age of the parent materials and the relatively dry climate of the island. Total elemental analyses show that the soils contain very low concentrations of potassium and important trace elements (iron, manganese, copper, and zinc), which will limit any plant production. Classification of the soils identified eight soil families, mainly separated on the basis of content of larger coarse fragments and soil moisture regime, including the influence of groundwater. Comparison with previous studies showed that although different nomenclature and classification systems were used, similar soil patterns were observed, and the soils of Kiritimati are relatively unique in the Pacific islands.
\end{abstract}

Kiritimati, located at $2^{\circ} 00^{\prime} \mathrm{N}, 157^{\circ} 30^{\prime}$ $\mathrm{W}$, is the largest atoll in the world in terms of land area $\left(\sim 320 \mathrm{~km}^{2}\right)$. The island was "discovered" by Captain Cook on 24 December 1777 and was named Christmas Island. It is located at the southern end of the Line Islands, which have a pronounced north-south wet-dry rainfall regime, with Kiritimati lying in the equatorial dry zone (Schott 1933), a narrow belt of low rainfall across the eastern central Pacific Ocean. Kiritimati has a population (2005 census) of over 5,000 (Secretariat of the Pacific Commission 2005), making it

\footnotetext{
${ }^{1}$ This work was supported by the Australia Pacific Science Foundation. Manuscript accepted 16 August 2008.

${ }^{2}$ Corresponding author (e-mail: johnm@uow.edu.au).

${ }^{3}$ GeoQuEST Research Centre, School of Earth and Environmental Sciences, University of Wollongong, NSW2522, Australia.

4 (e-mail: colin@uow.edu.au).
}

Pacific Science (2009), vol. 63, no. 3:397-411

(C) 2009 by University of Hawai'i Press

All rights reserved one of the most highly populated single-atoll islands. The population has risen markedly since the early 1990s, when the government of Kiribati started encouraging people to move to Kiribati to reduce population pressure on the Gilbert group, especially Tarawa. Such an increase will have impacts on the natural resources of Kiritimati, especially its soils and water.

The island is shaped somewhat like a lobster claw (Figure 1) with a lagoon covering some $160 \mathrm{~km}^{2}$ occupying much of the western end of the island. East of the main lagoon is a central area containing more than 500 saline or hypersaline lagoons covering some $140 \mathrm{~km}^{2}$ that have been the subject of several studies (Valencia 1977, Trichet et al. 2001, Saenger et al. 2006) because they present relatively unique environments for algal growth. There is a limited tourism industry based on recreational fishing and bird watching, but copra production is still a major component of the local economy. Local food production is now also a priority, and knowledge of the soils is essential for sustaining the local population. 


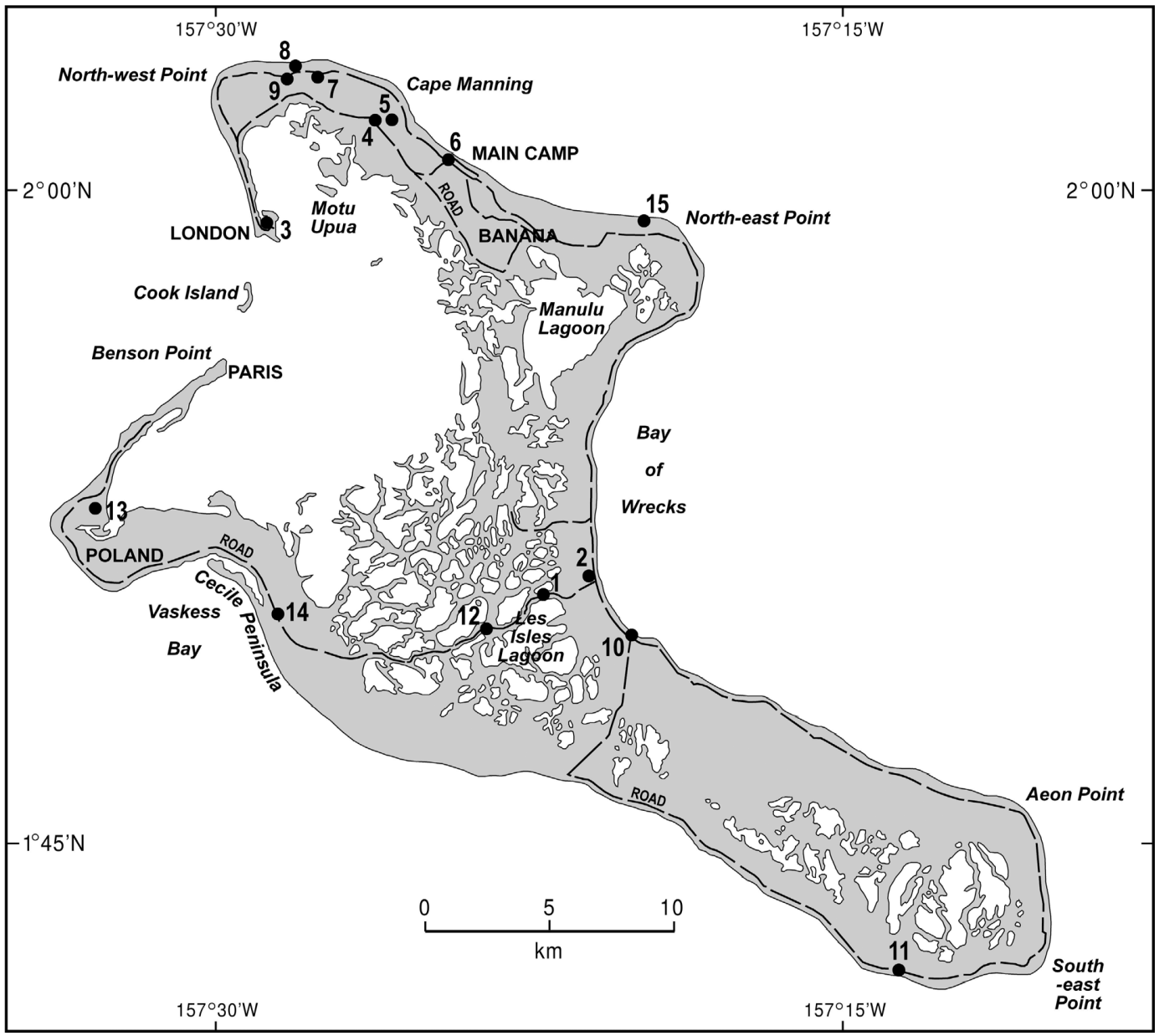

Figure 1. Map of Kiritimati showing locations of the soil profiles studied.

Information on the soils of Kiritimati is substantially better than that for most atolls in the Pacific as a result of two studies completed in the 1960s by Jenkin and Foale (1968) and Hammond (1969), which are commented on further in the next section. Those reports are now over $30 \mathrm{yr}$ old, and this study was initiated to make available some morecurrent information for decision makers on the future of Kiritimati. This study involved a site visit to the island; description, sampling, and analysis of key soils; and comparison with the results of previous investigations.

\section{Previous Studies on Soils and Environment of Kiritimati}

Early comments on the soils of Kiritimati can be found in Christopherson (1927) and Wentworth (1931), but they were mainly interested in the vegetation and geology of the island. Although there was a spurt of interest in atoll soils in the post-World War II era (e.g., Stone 1951, Fosberg 1954), limited attention was paid to the "dry" atolls until the 1960s, when two notable studies on Kiritimati were completed by Jenkin and Foale (1968) 
and Hammond (1969). The former was an investigation of the coconut-growing potential of the island, and the latter was a more traditional pedological study. These two studies produced valuable information but were somewhat limited by the analytical facilities available at the time.

Jenkin and Foale (1968) divided the soils into two associations depending on the depositional mode of the patent materials: oceanic deposits and lagoon deposits. The oceanic deposits were further differentiated on the basis of particle size (sands, mixed coral sand + gravel + rubble, and coral rubble), with the coral sands being separated into three types based on location and associated vegetation type: young beach sands, coastal dune sands, and older beach sands. The lagoon-deposit soils were differentiated on the basis of the presence or absence of a hardpan. Laboratory information obtained included $\mathrm{pH}$ (in $\mathrm{H}_{2} \mathrm{O}$ and $\mathrm{CaCl}_{2}$ ), \% $\mathrm{CaCO}_{3}$, $\%$ organic $\mathrm{C}, \% \mathrm{~N}$, total $\mathrm{K}, \mathrm{P}_{2} \mathrm{O}_{5}, \mathrm{Mg}, \mathrm{Na}$, and Sr. Attempts were made to measure trace elements (e.g., $\mathrm{Cu}, \mathrm{Fe}, \mathrm{Mn}, \mathrm{Mo}, \mathrm{V}$, and $\mathrm{Zn}$ ), but in almost all cases the results were below the detection limits available at the time. Low concentrations of trace elements are common in atoll soils derived from coral limestone having a relatively high $\mathrm{pH}$ (Morrison 1992). Jenkin and Foale (1968) did not complete any detailed classification of the soils but considered them as Entisols, Lithosols, and Regosols, because they showed minimal profile development.

Hammond (1969) examined and described about 30 pedons around the island. He also completed laboratory analyses including petrographic examination, mineralogy by X-ray diffraction, particle size distribution, major total element analysis $\left(\mathrm{Ca}, \mathrm{Mg}, \mathrm{P}_{2} \mathrm{O}_{5}, \mathrm{Na}, \mathrm{K}\right.$, and $\left.\mathrm{SiO}_{2}\right), \%$ organic $\mathrm{C}, \% \mathrm{~N}, \mathrm{pH}$, and electrical conductivity. He found minimal change in the total element chemistry between the soils and the parent materials, confirming their youthfulness. He divided the soils into seven categories, separated on the basis of landform position, particle size distribution, and hardpan presence/absence. Except for one category, unaltered sand and gravel, all the soils were considered phases of the Shioya soil series. This was based on similarity in profiles with the Shioya soils originally mapped on Okinawa but found also in Arno (Stone 1951) and the northern Marshall Islands (Fosberg and Carroll 1965). As noted by Morrison (1990), there is an issue with including these Kiritimati soils in the same series as those from the wetter western Pacific islands; they would be separated at the great group level in Soil Taxonomy (Soil Survey Staff 1999) based on the prevailing moisture regime because the Shioya series soils were previously mapped on higher-rainfall locations. Six mapping units were included in Hammond's (1969) soil map (the Shioya gravelly phase was of insufficient distribution to map separately). Organic matter contents were low, $\mathrm{C}: \mathrm{N}$ ratios average about 12 , and the $\mathrm{pHs}$ were high $(>7.7)$. Potassium concentrations were very low, and most of the phosphorus was found in the surface horizons; no trace element information was collected.

\section{Soil-Forming Factors on Kiritimati}

climate. As noted earlier, Kiritimati is in the equatorial dry zone and receives substantially lower rainfall than islands to the north, south, and west. The average annual rainfall is $914 \mathrm{~mm}$ (based on data from 1951 to 2006) but is extremely variable, ranging from $177 \mathrm{~mm}$ in 1954 to 2,959 $\mathrm{mm}$ in 1987 (Figure 2). These large variations are linked to variations in the El Niño-Southern Oscillation (ENSO) phenomenon, with high rainfalls occurring during El Niño episodes and droughts in the intervening periods (Falkland and Woodroffe 1997). Falkland and Woodroffe (1997) reported that there is a strong correlation between annual rainfall and the Southern Oscillation Index (SOI). Evapotranspiration is high (Jenkin and Foale 1968), with estimates often exceeding annual rainfall, confirming the relative aridity of the island. The applicability of some of the equations to calculate potential evapotranspiration in a situation like Kiritimati is questionable given the high porosity of many of the soils, 


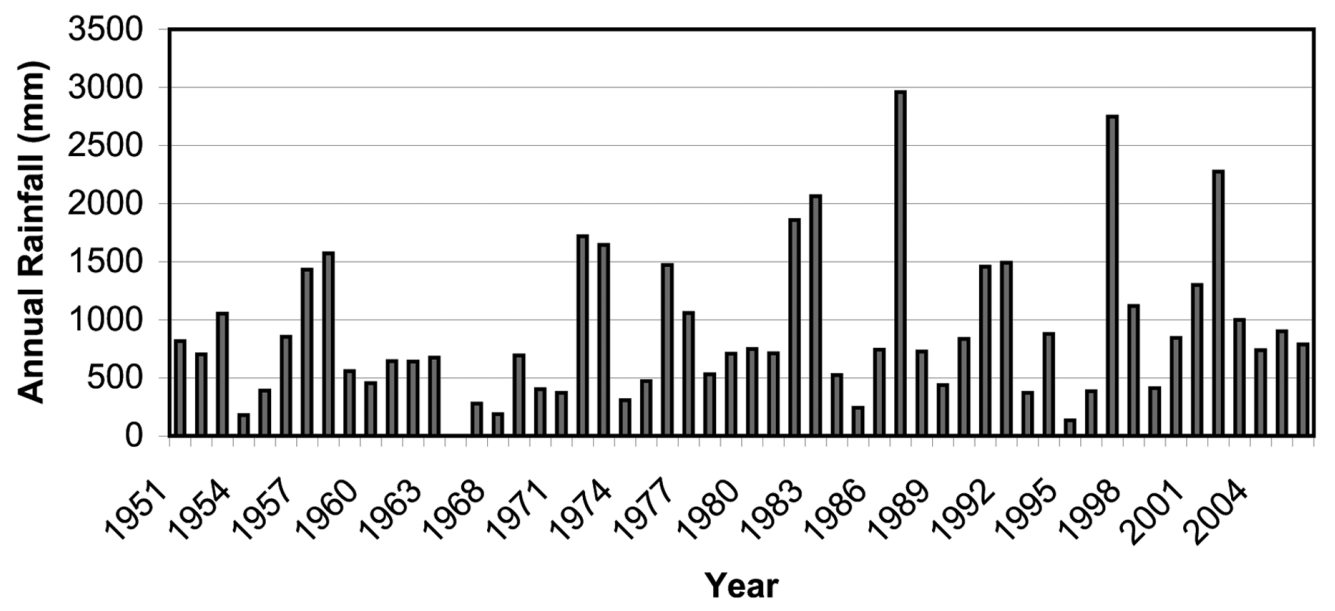

Figure 2. Annual rainfall (mm/yr) for Kiritimati, 1951-2006.

with water moving through the profiles before evaporation could occur.

The mean annual temperature on Kiritimati is $27.5^{\circ} \mathrm{C}$, with limited variation (mean monthly maximum about $30.3^{\circ} \mathrm{C}$ and mean minimum about $24.6^{\circ} \mathrm{C}$ [Kiribati Meteorological Service, pers. comm.]). Winds are predominantly easterlies, but infrequent northeasterlies are important because they are the main winds bringing rain.

PARENT MATERIAL. The soils are derived from calcareous reef materials composed of Foraminifera tests, coral remains, and shells of mollusks and other marine organisms. Soil differences arise from variations in the size of the fragments, with the mode of deposition being important (lagoon or nonlagoon deposits). Chemically, the materials are predominantly aragonite (Hammond 1969 ) with calcite usually less than $50 \%$. High-magnesium calcite is usually more abundant than low-magnesium calcite. Aragonite is highest in the coarser materials, and low-magnesium calcite becomes more important in the finest materials. These results differ from those of Fosberg and Carroll (1965) for the northern Marshall Islands atolls and Woodroffe and Morrison (2001) for Makin in the northern Gilberts, where calcite was found to be dominant. All those authors indicated that calcite is abundant where Foraminifera are the major sediment source.

In terms of particle size the parent materials are dominated by sands, with the quantities for coarser material $(>2 \mathrm{~mm})$ varying with location. The proportions of very fine sand + silt + clay are always less than $5 \%$.

RELIEF/LANDFORM/GEOLOGY. The morphology of Kiritimati reflects that of the underlying Pleistocene limestone. Highly karstifed limestone of last interglacial age outcrops on the northern shore and may have been more extensive before phosphate mining. Drilling indicates that this limestone is underlain at shallow depths by a midPleistocene limestone platform $(>200 \mathrm{ka})$. The shallow depths of these older limestones implies that the atoll has not been subsiding; they have been slightly weathered and covered with a veneer of Holocene calcareous sand and gravel material (Woodroffe and McLean 1998). The Pleistocene subsurface materials in the middle of the island are dominated by mollusk-rich marls, with the top $18 \mathrm{~m}$ being predominantly aragonitic (Falkland and Woodroffe 1977). Dating from water boreholes indicates Holocene accumulations over the last 5,000 yr BP, and Woodroffe and McLean (1998) inferred emergence since about 1,500 yr BP, following a relative fall in local sea level of $0.5-1 \mathrm{~m}$. 
The original volcanism forming the base of the island is considered Cretaceous to Late Eocene (Schlanger et al. 1984), with the limestone cap varying in thickness from about 30 $\mathrm{m}$ to over $120 \mathrm{~m}$ (Jenkin and Foale 1968).

Kiritimati is a low atoll, but Jenkin and Foale (1968) and Woodroffe and McLean (1998) described a number of landscape features. These include the narrow $(30-120 \mathrm{~m})$ fringing reef with a spur and groove system on the reef front. The adjacent seaward beaches are generally steep and composed mainly of coarse shingle and rubble. Behind the modern beach is a sequence of shingle ridges and swales rising 3-4 $\mathrm{m}$ above sea level (referred to as a beach crest by Jenkin and Foale [1968]). In the eastern part of the island around the Bay of Wrecks these ridges are replaced by dunes that rise to the highest point on the island (Joe's Hill, $\sim 13 \mathrm{~m}$ ). Inland of the beach crest, Jenkin and Foale (1968) differentiated a central ridge that is particularly pronounced along the northwestern arm of the island. This central ridge has inland dune systems rising to $5 \mathrm{~m}$ above sea level and in the northeast and southwest corners of the island is separated from the current coast by a lower-lying coastal plain with landlocked hypersaline lakes (Falkland and Woodroffe 1997). The central ridge is bounded on the lagoon side by a $1 \mathrm{~m}$ scarp, which in turn is bordered by a low-lying $(\sim 1$ $\mathrm{m})$ broad lagoon flat, across which is scattered many saline and hypersaline lakes.

HYDRology. As noted earlier, Kiritimati has very variable annual rainfall, and most of the soil materials are highly porous with very limited moisture-retention capacity. Thus moisture is likely to be a limiting factor in plant growth and hence in the production of organic matter for soil formation. Groundwater is another water source and several freshwater lenses have been identified (Falkland and Woodroffe 1997). These are considered to be discontinuous despite the relatively large size of the island; this may be due to major lateral variations in substratum hydraulic conductivity, which in turn may arise from lateral variations in the depth to the unconformity between Holocene and Pleistocene deposits. Several authors (Jenkin and Foale
1968, Falkland and Woodroffe 1997) have reported that vegetation is not a good predictor of the presence of fresh groundwater. Estimates of groundwater lens recharge show that these are related (inversely) to the extent of tree coverage and range from about $10 \%$ to $25 \%$ of the mean annual rainfall (Falkland and Woodroffe 1997).

VEgETATION/Fauna. The vegetation of Kiritimati has been described in several reports (Christopherson 1927, Chock and Hamilton 1962, Jenkin and Foale 1968, Wester 1985). Coconut plantations cover over 5,000 ha but, based on reports from early visitors to the island, are a relatively recent introduction (Jenkin and Foale 1968). These plantations were created by clearing extensive areas of the native vegetation, particularly in areas where water lenses were relatively close to the surface. The remaining sparse native vegetation consists of associations between Tournefortia argentea with Sida fallax, Scaevola taccada, or Suriana maritima; low shrub associations dominated by Scaevola taccada, Sida fallax, and Suriana maritima; or grasslands dominated by Lepturus repens, Boerbavia tetrandra, and Sesuvium portulacastrum.

The only fauna having any influence on soils are the seabirds (including the abundant sooty tern, Sterna fuscata oabensis) and land crabs (Cardiosoma carniflex), which burrow into the soil. The birds deposit guano where they dwell, and this has been considered very important in soil formation in other atolls (Fosberg 1954).

TIME. As noted earlier, it is estimated that the current soils have been formed since the surface of the island formed during the last 5,000 yr (Woodroffe and McLean 1998). Thus only a limited time has been available for soil formation.

humans. Historically, Kiritimati has had a small population. There is no record of an indigenous population before Cook's discovery, although historians consider that visits by Polynesians traveling between Hawai' $\mathrm{i}$ and Tahiti were probable, and a possible visit by the Spaniard Alvarado in 1537 has been postulated. Jenkin and Foale (1968) reported a population of less than 50 in the period 1900-1940, but during World War II some 
10,000 Allied troops were stationed there. During the British atomic tests in the late 1950 s up to 5,000 personnel were located on Kiritimati, but after that activity finished in the early 1960s, the population was about 300 . This has risen steadily since, with a dramatic increase (doubling) from the early 1990s to 2005. Between World War I and World War II, the island was leased to a French priest, Father Emmanuel Rougier, who planted some 800,000 coconut tees. This represented the first major human impact on the island because extensive areas of native vegetation, especially the Tournefortial Sida association, were removed during planting. The World War II and postwar nuclear testing led to further vegetation removal, and some construction activities caused localized landform disturbance.

\section{MATERIALS AND METHODS}

\section{Field Studies}

Following a review of the information in Jenkin and Foale (1968) and Hammond (1969) and a reconnaissance survey of the whole island, areas within the main geomorphological sections of the island were identified. Within each identified area, a preliminary auger survey was made to determine the extent of soil variability (which was generally very limited) and the general soil pattern and to identify the dominant profile types. Pits were dug in what was considered the dominant profile type at each site, the profiles were described, and samples of soils according to horizons were collected for laboratory examination. Fifteen pedons were described and sampled. The locations of the pedons described are shown in Figure 1. Full site and profile descriptions for representative major soil types are given in the Appendix.

\section{Laboratory Studies}

Soil samples were air dried and subsamples ground to pass through a $2 \mathrm{~mm}$ sieve. Small subsamples were further ground to pass through a $250 \mu \mathrm{m}$ sieve. These finer samples were used for the organic carbon and total element analyses, and the $<2 \mathrm{~mm}$ samples were used for the other analyses. Chemical parameters were measured using the methods of Blakemore et al. (1981) with the following exceptions. Organic carbon was determined by the Walkley-Black procedure with silver sulfate added to the sulfuric acid to remove the interference from chloride ion (Lee et al. 1982). For the total elemental analyses, soil samples, together with a certified reference material (NRCC Marine Sediment Reference Material No. PASC-1), were digested using a mixture of hydrofluoric, perchloric, hydrochloric, and nitric acids, followed by analysis by inductively coupled plasma-optical emission spectrophotometry (ICP-OES: $\mathrm{Ca}, \mathrm{Mg}$, $\mathrm{Fe}, \mathrm{Al}, \mathrm{K}, \mathrm{Na}, \mathrm{Sr}, \mathrm{P}$ ) or inductively coupled plasma-mass spectrometry (ICP-MS: As, Cd, $\mathrm{Co}, \mathrm{Cr}, \mathrm{Cu}, \mathrm{Mn}, \mathrm{Ni}, \mathrm{Pb}, \mathrm{Se}, \mathrm{Sn}, \mathrm{V}, \mathrm{Zn})$. There was generally good agreement between the measured data and the certified values for the reference material.

Linear regression analysis was used in statistical treatments.

\section{RESULTS AND DISCUSSION}

\section{Field Observations}

As expected from the information presented, the Kiritimati soil profiles (see Appendix) are generally very weakly developed. There are no very dark (value $<4$ ) horizons that are found in soils from wetter atolls, effectively no soil structure, and textures are sandy or coarser. There is a substantial influence of larger $(>2 \mathrm{~mm})$ fragments, particularly in the soils derived from the lagoonal deposits where they vary in depth and concentration. The occurrence of hardpans is of interest because this is not often observed in the soils of other atolls, but again this may be an outcome of the substantial area of soils derived from lagoon deposits. The soil profiles are very similar to those described by Jenkin and Foale (1968) and Hammond (1969).

\section{Laboratory Data}

Some chemical properties of the Kiritimati soils are summarized in Table 1 . Where sim- 


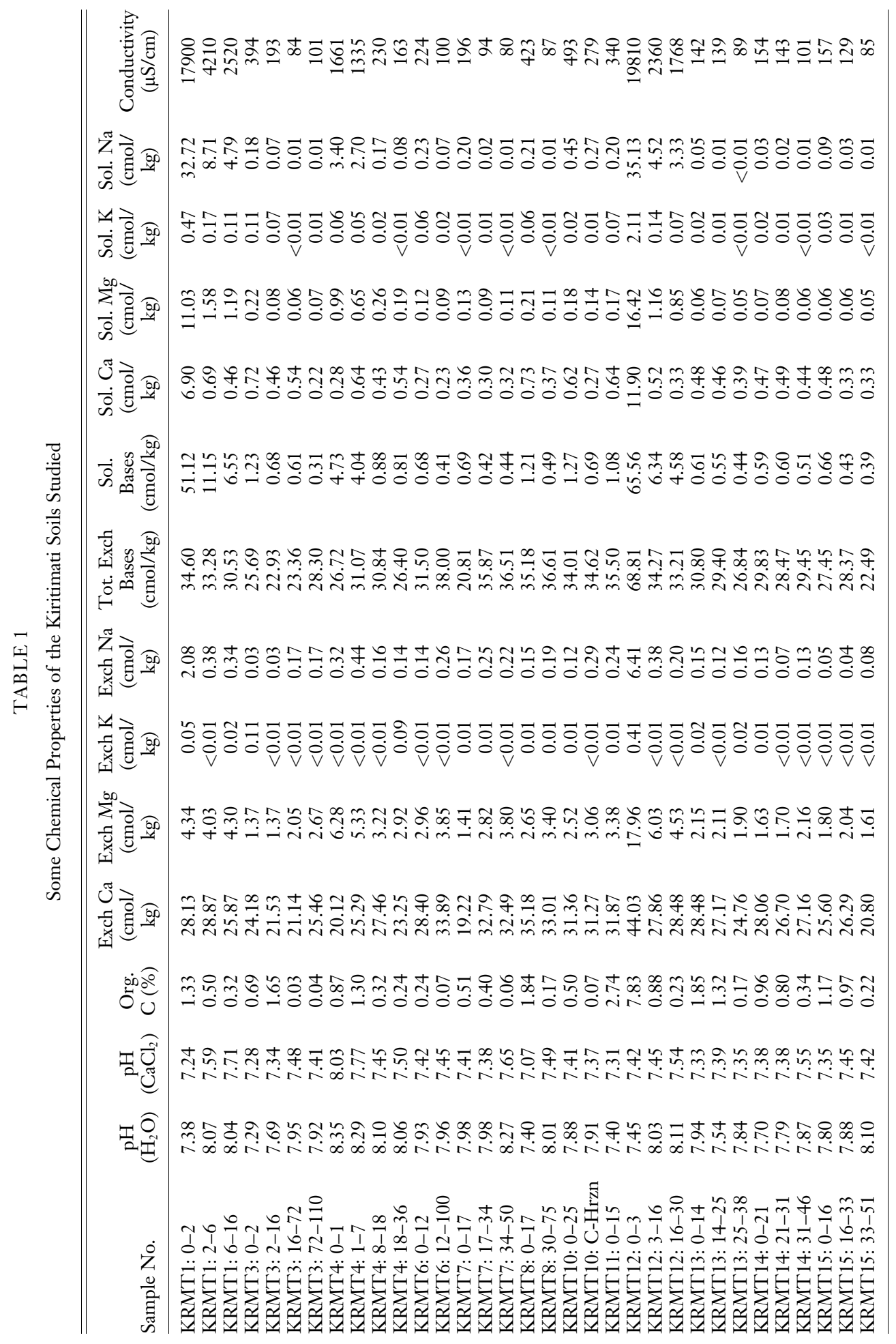


ilar observations were made, the results compare well with those of previous studies. $\mathrm{pH}$ values ranged from 7.4 to 8.3 in water and from 7.2 to 8.1 in $\mathrm{CaCl}_{2}$. Jenkin and Foale (1968) found values ranging from 7.9 to 9.2 in water and from 7.3 to 8.9 in $\mathrm{CaCl}_{2}$, and Hammond found values of 7.7-8.8 in water. Organic carbon contents ranged from $0.24 \%$ to $7.83 \%$ for topsoils and $0.03 \%-1.32 \%$ for subsoils. Jenkin and Foale (1968) found a range of $0.3 \%-2.3 \%$ for topsoils and $0.06 \%-$ $0.7 \%$ for subsoils; Hammond's (1969) values ranged from $0.22 \%$ to $1.35 \%$ for topsoils and from $0.16 \%$ to $0.41 \%$ for subsoils. The highest organic carbon values $(2.74 \%$ and $7.83 \%$ ) found in this study were from profiles located under mature Tournefortia trees in stable landscapes (profiles KRMT 11 and 12), confirming the importance of trees in providing organic matter additions to the soils. Comparing the Kiritimati soils organic carbon data with those from other atolls shows that the average topsoil value $(1.75 \%)$ is substantially lower than for wetter atolls. Average organic carbon \% for topsoils in Bonriki/Bikenibeu (South Tarawa, average rainfall $2,024 \mathrm{~mm} / \mathrm{yr}$ ) was $4.48 \%$ (Seru and Morrison 1985), for Abatao (Tarawa) was $10.37 \%$ (Morrison and Seru 1985), and for Makin (average rainfall 3,129 mm/yr) was 4.39\% (Woodroffe and Morrison 2001). The South Tarawa and Makin soils had also been highly disturbed relative to the Abatao sites at the time of sampling, but even undisturbed sites on Kiritimati recorded relatively low organic carbon $\%$.

Measurements of exchangeable bases showed that potassium $(\mathrm{K})$ contents were extremely low, with almost all values $<0.1$ $\mathrm{cmol} / \mathrm{kg}$ and many $<0.01 \mathrm{cmol} / \mathrm{kg}$. The only exception to this was KRMT 12, found under a Tournefortia tree in a location where some seawater influence may have occurred (see later in this section). These values confirm the extreme limitations to plant growth caused by potassium on Kiritimati. There is no comparable exchangeable base data from previous studies, but the values found for calcium, magnesium, and sodium are comparable with values found for other atolls (Morrison and Seru 1985, Woodroffe and
Morrison 2001, Deenik and Yost 2006). A very strong correlation was found between the electrical conductivity and the sum of soluble bases $(r>0.99)$, with the highest values found for soils derived from lagoonal deposits.

Total element analyses (Table 2) of the soils gave results similar to those of earlier work where comparable analyses were completed (e.g., for $\mathrm{Ca}, \mathrm{Mg}, \mathrm{K}$, and $\mathrm{Na}$ [Hammond 1968]). This is the first report of actual trace elemental data because Jenkin and Foale (1968) reported trace element data as below then-available detection limits. In this study, many elements, as expected, recorded very low concentrations. For $\mathrm{Al}$, As, $\mathrm{Co}, \mathrm{Cr}, \mathrm{Ni}, \mathrm{Pb}, \mathrm{Se}$, and $\mathrm{V}$ almost all values were below or close to the detection limit. This is also true for $\mathrm{Fe}$ and $\mathrm{Mn}$, confirming the critical shortage of these elements in atoll soils. The concentrations of $\mathrm{Cu}, \mathrm{Sn}$, and $\mathrm{Zn}$ were also extremely low. The total $\mathrm{K}$ data are very low for soils, but it is notable that the highest total concentration was found for the soil with the highest exchangeable $K$ value (KRMT 12, 0-3 cm). For P, high $(>1 \% \mathrm{P})$ concentrations were found for KRMT 11 , 13 , and 15 . These sites are either currently under Tournefortia vegetation or were considered covered with Tournefortia vegetation in the past (Jenkin and Foale 1968). This is in line with the importance of these trees as roosting sites for birds, which, in turn, has led to guano deposition under them. This is confirmed by the very strong correlations between $\mathrm{P}$ and $\mathrm{Cd}\left(r^{2}=0.96\right)$. Strong links between $\mathrm{P}$ and $\mathrm{Cd}$ are known for oceanic waters (Frew and Hunter 1995), and phosphatic materials based on seabird deposits elsewhere are known to have high $\mathrm{Cd}$ contents (e.g., Morrison and Manner 2005). Strong correlations were also found between $\mathrm{P}$ and $\mathrm{Zn}\left(r^{2}=0.96\right)$ and $\mathrm{Cd}$ and $\mathrm{Zn}$ $\left(r^{2}=0.92\right)$. Significant $(P<.05)$ but weaker correlations were also found between $\mathrm{P}$ and $\mathrm{Mn}$ and $\mathrm{Cu}$, and a negative correlation between $\mathrm{Ca}$ and $\mathrm{K}$.

Although no specific measurements were made on plant-available trace elements, given the high $\mathrm{pHs}$ of the soils and the very low total concentrations, the availability of trace 


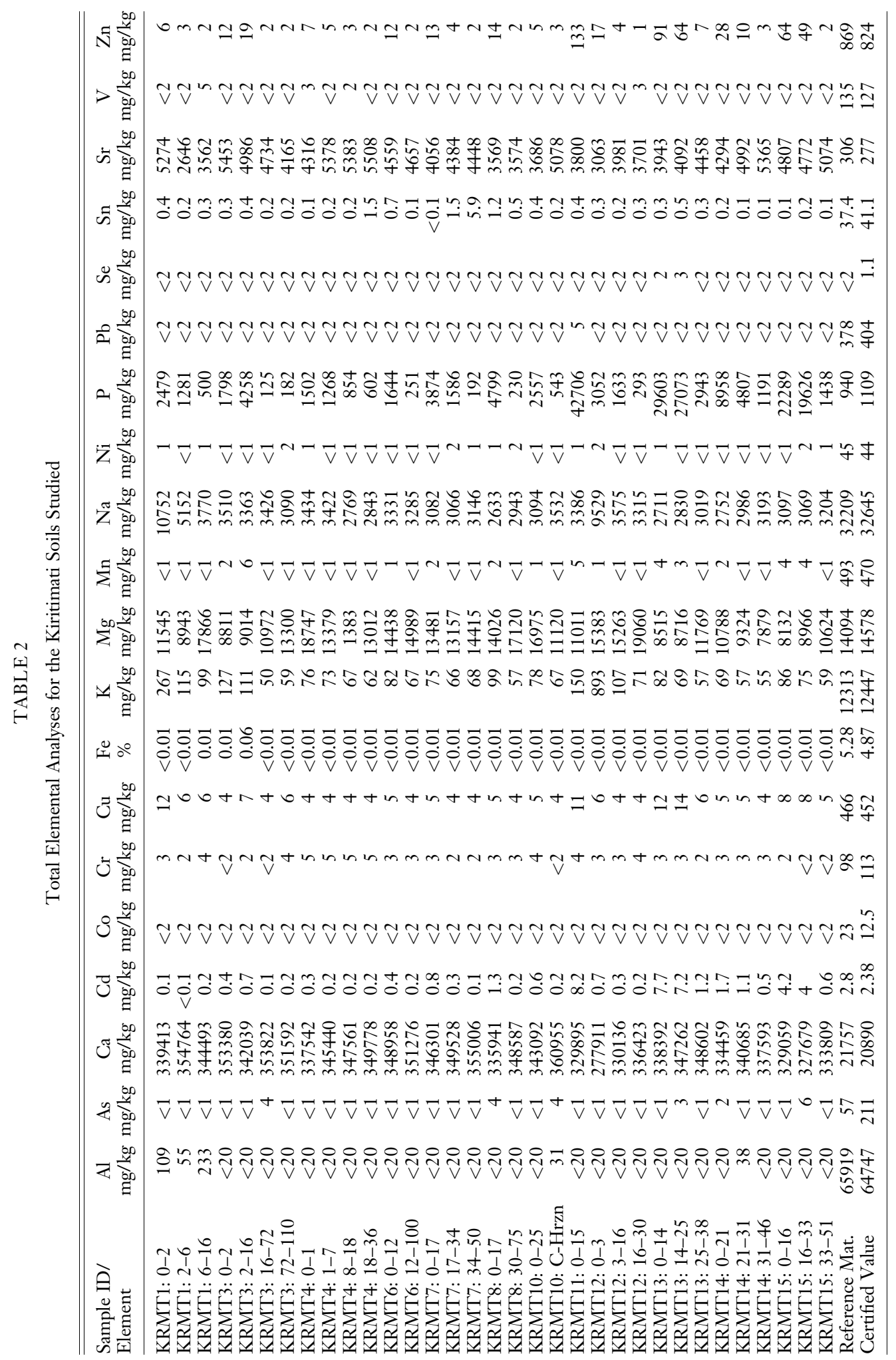


elements (especially $\mathrm{Fe}, \mathrm{Mn}, \mathrm{Cu}, \mathrm{Zn}$, and $\mathrm{Co}$ ) is likely to be minimal (Morrison 1992), and any substantial plant/crop production will require additions of these elements. No direct measurements of plant-available $\mathrm{P}$ were made, but assessment of plant-available values (Olsen test) using correlations with total $\mathrm{P}$ derived elsewhere (e.g., Samadi and Gilkes 1998) show that the range of values expected $(1-30 \mathrm{mg} / \mathrm{kg})$ is similar to that found for Marshall Island soils by Deenik and Yost (2006). Care will have to be taken in any nu- trient addition programs to avoid additions to the soil when heavy rains are expected because the excessively good drainage of many Kiritimati soils could lead to rapid leaching losses after heavy rain.

\section{Classification of Soils}

Classifications (Soil Survey Staff 1999) of the Kiritimati soils examined are listed in Table 3 . As expected for very young soils, they are all Entisols. Separation at lower categories is

TABLE 3

Relationship of Soil Information from This Study with That in Previous Work

\begin{tabular}{|c|c|c|c|}
\hline This Study & Hammond (1969) & Jenkin and Foale (1968) & $\begin{array}{c}\text { Soil Classification } \\
\text { (Soil Survey Staff 1999) }\end{array}$ \\
\hline KRMT 1 & $\begin{array}{l}\text { Coarser equivalent of profile } \\
104 \text { (Te Bam: soil derived } \\
\text { from lagoon-deposited } \\
\text { sediment) }\end{array}$ & $\begin{array}{l}\text { Coarser variation of lagoon } \\
\text { mud without hardpan } \\
\text { soil (profile 66) }\end{array}$ & $\begin{array}{l}\text { Medial-skeletal, carbonatic, } \\
\text { isohyperthermic Oxyaquic } \\
\text { Ustorthent }\end{array}$ \\
\hline KRMT 2 & $\begin{array}{l}\text { Similar to profile } 116 \text { (Taura: } \\
\text { from lagoon-deposited } \\
\text { sediment) }\end{array}$ & $\begin{array}{l}\text { Mixed coral sand, gravel, } \\
\text { and rubble }\end{array}$ & $\begin{array}{l}\text { Sandy-skeletal, carbonatic, } \\
\text { isohyperthermic Typic } \\
\text { Ustorthent }\end{array}$ \\
\hline KRMT 3 & $\begin{array}{l}\text { Profile } 101 \text { (Shioya?) but more } \\
\text { groundwater influence }\end{array}$ & Mixed coral sand soil & $\begin{array}{l}\text { Carbonatic, isohyperthermic } \\
\text { Typic Ustipsamment }\end{array}$ \\
\hline KRMT 4 & $\begin{array}{l}\text { Located close to profile } 107 ; \\
\text { no description given }\end{array}$ & $\begin{array}{l}\text { Coral sand overlying } \\
\text { lagoon mud (profile 25) }\end{array}$ & $\begin{array}{l}\text { Carbonatic, isohyperthermic } \\
\text { Typic Psammaqent }\end{array}$ \\
\hline KRMT 5 & $\begin{array}{l}\text { Located close to profile } 107 ; \\
\text { no description given }\end{array}$ & $\begin{array}{l}\text { Coral sand overlying } \\
\text { lagoon mud (profile 25) }\end{array}$ & $\begin{array}{c}\text { Carbonatic, isohyperthermic } \\
\text { Oxyaquic Ustipsamment }\end{array}$ \\
\hline KRMT 6 & $\begin{array}{l}\text { Similar to profile } 127 \text { (Dune: } \\
\text { from windblown sand) }\end{array}$ & $\begin{array}{l}\text { Coastal sand dune soil } \\
\quad \text { (profile 58) }\end{array}$ & $\begin{array}{l}\text { Carbonatic, isohyperthermic } \\
\text { Aridic Ustipsamment }\end{array}$ \\
\hline KRMT 7 & Profiles 106/108 (Shioya?) & $\begin{array}{l}\text { Older beach sand soil } \\
\quad \text { (profile 1) }\end{array}$ & $\begin{array}{l}\text { Carbonatic, isohyperthermic } \\
\text { Typic Ustipsamment }\end{array}$ \\
\hline KRMT 8 & Profile 108 (Shioya?) & $\begin{array}{l}\text { Older beach sand soil } \\
\quad \text { (profile } 1)\end{array}$ & $\begin{array}{l}\text { Carbonatic, isohyperthermic } \\
\text { Typic Ustipsamment }\end{array}$ \\
\hline KRMT 9 & Profiles 106/108 (Shioya?) & $\begin{array}{l}\text { Older beach sand soil } \\
\text { (profile 1) }\end{array}$ & $\begin{array}{l}\text { Carbonatic, isohyperthermic } \\
\text { Typic Ustipsamment }\end{array}$ \\
\hline KRMT 10 & $\begin{array}{l}\text { Profile } 127 \text { (Dune: from } \\
\text { windblown sand) }\end{array}$ & $\begin{array}{l}\text { Coastal sand dune soil } \\
\quad \text { (profile } 58)\end{array}$ & $\begin{array}{l}\text { Carbonatic, isohyperthermic } \\
\text { Aridic Ustipsamment }\end{array}$ \\
\hline KRMT 11 & $\begin{array}{l}\text { Possibly profile } 119 ; \text { no } \\
\text { description given }\end{array}$ & $\begin{array}{l}\text { Mixed coral sand/coastal } \\
\text { sand dune soil (profile } \\
58 \text { ) }\end{array}$ & $\begin{array}{l}\text { Sandy-skeletal, carbonatic, } \\
\text { isohyperthermic Aridic } \\
\text { Ustorthent }\end{array}$ \\
\hline KRMT 12 & $\begin{array}{l}\text { Closest equivalent profile } 104 \\
\text { (Te Bam: soil derived from } \\
\text { lagoon-deposited sediment) }\end{array}$ & $\begin{array}{l}\text { Lagoon mud without } \\
\text { hardpan soil (profile 66) }\end{array}$ & $\begin{array}{l}\text { Sandy-skeletal, carbonatic, } \\
\text { isohyperthermic Oxyaquic } \\
\text { Ustorthent }\end{array}$ \\
\hline KRMT 13 & Profile 114 (Shioya?) & $\begin{array}{l}\text { Older beach sand soil } \\
\quad \text { (profile 91) }\end{array}$ & $\begin{array}{l}\text { Carbonatic, isohyperthermic } \\
\text { Typic Ustipsamment }\end{array}$ \\
\hline KRMT 14 & Profile 114 (Shioya) & $\begin{array}{l}\text { Older beach sand soil } \\
\quad \text { (profile 91) }\end{array}$ & $\begin{array}{l}\text { Carbonatic, isohyperthermic } \\
\text { Typic Ustipsamment }\end{array}$ \\
\hline KRMT 15 & $\begin{array}{l}\text { Profile } 108 \text { (Shioya?) and } \\
\text { possibly } 103 \text { (Decca: } \\
\text { derived from ocean- } \\
\text { deposited sediment) }\end{array}$ & $\begin{array}{l}\text { Older beach sand/mixed } \\
\text { coral, sand, and gravel } \\
\text { (more gravels than } \\
\text { profile 91) }\end{array}$ & $\begin{array}{l}\text { Sandy-skeletal over sandy, } \\
\text { carbonatic, isohyperthermic } \\
\text { Typic Ustipsamment }\end{array}$ \\
\hline
\end{tabular}


based on the particle size class (mainly the extent of fragments $>2 \mathrm{~mm}$ diameter) and the soil moisture regime. Determination of the soil moisture regime for Kiritimati soils is problematic because of the great variability in annual rainfall, the depth to which profile drying by evaporation occurs, the extent of groundwater movement up the profiles, and the salinity of the groundwater. Groundwater influences are also substantially impacted by rainfall, with some areas being saturated to near the surface in wet years but having limited groundwater penetration into the control section in dry years. Based on the available information, most soils were considered to have an ustic soil moisture regime (Soil Survey Staff 1999) (i.e., being dry in some or all parts of the soil moisture control section for 90 or more cumulative days in normal years). Soils on the higher dunes (e.g., KRMT 10), being excessively well drained and unlikely to have any groundwater incursion into the control section, may even have aridic soil moisture regimes, but this could not be confirmed, and so they were classified into the Aridic subgroup of Ustipsamments.

Jenkin and Foale (1968) did not undertake any classification of the soils other than to list them as recent soils (Entisols, Regosols, Lithosols). Hammond (1969), as noted earlier, classified all the soils as various phases of the Shioya series, based on comparison with profiles from the Marshall Islands. Using information from Stone (1951), the Shioya series would be a member of the carbonatic, isohyperthermic Typic Udipsamments family (Soil Survey Staff 1999) (i.e., a wetter Entisol than any found on Kiritimati). Thus, the use of the Shioya series designation on Kiritimati is inappropriate. There is greater similarity between the Kiritimati soils and the Jaucas series mapped in Hawaili (Foote et al. 1972), because this coastal sand soil series has an ustic moisture regime, but the Jaucas soils may have some small inputs of noncalcareous materials.

Overall, eight soil families were identified in this study; this may appear high for an atoll, but given the different parent material deposition modes, the influence of materials $>2 \mathrm{~mm}$ diameter, and the role of groundwater intrusion, this is not entirely surprising. Knowledge of these variations in the soils of Kiritimati is important for decision making on the use of the soils to support the local population.

\section{Comparison with Previous Studies}

Table 3 presents a correlation between the pedons described in this study and the work of Jenkin and Foale (1968) and Hammond (1969). In most cases it was possible to identify corresponding soils in the earlier work, but Hammond did not describe any profiles in the lagoon where KRMT 1 and 12 are located. The mapping units used by Jenkin and Foale (1968) and Hammond (1969) differ in terminology, but the outcomes in terms of soil utilization are relatively similar.

In this study, two soil families were prevalent: carbonatic, isohyperthermic Typic Ustipsamments and medial/sandy-skeletal carbonatic, isohyperthermic Oxyaquic Ustorthents. For the latter family, the closely related Typic Ustorthents would be found in close association, differences depending on the influence of groundwater, which varies substantially across the central section of the island. These two families correspond quite well to the two main soil categories described by Jenkin and Foale (1968): soils from oceanic deposits and soils from lagoon deposits. Similarly, Hammond (1969:24) grouped his soils initially into those derived from wind/ ocean deposits (Dune, Decca, and Te Marae soils) and those derived from lagoondeposited sediment ( $\mathrm{Te}$ Bam, Te Bue, and Taura soils). Thus, all three studies have produced similar overall results although there are some minor differences in the details.

\section{CONCLUSIONS}

This study has confirmed many of the outcomes of previous work on the soils of Kiritimati and has shown that the soils are generally only weakly developed with low organic matter contents. The coarseness of the soils means that water-retention capacity will be very low in all soils. There are very low total concentrations of essential nutrients, es- 
pecially potassium, iron, manganese, copper, and zinc; this means that the plant-available quantities will be minimal, particularly because the soils have high $\mathrm{pH}$ values. Given the relatively dry environment on the island, production of food crops to support the expanding local population will have to be carefully managed in terms of crop selection, water utilization, and the addition of essential nutrients. The occurrence of hardpans in soils covering extensive areas of the island is also likely to limit production of food crops.

\section{ACKNOWLEDGMENTS}

We gratefully acknowledge the support of this work by the Australia Pacific Science Foundation. Much of the manuscript was drafted while R.J.M. was a Visiting Fellow at the Pacific Islands Development Program (PIDP), East-West Center, in Honolulu; the hospitality of PIDP staff assisted considerably in this regard. We are also grateful to Ms. Naomi Atauea of the Kiribati Ministry of Natural Resources Development for assistance with the local logistics; to the Kiribati Meteorological Service for provision of rainfall data; and to D. M. Kennedy, who assisted with the fieldwork.

\section{Literature Cited}

Blakemore, L. C., P. L. Searle, and B. K. Daly. 1981. Methods of chemical analysis of soils. N. Z. Soil Bur. Sci. Rep. 10A (Revised).

Chock, A., and D. C. Hamilton. 1962. Plants of Christmas Island. Atoll Res. Bull. 90:17.

Christopherson, E. 1927. Vegetation of the Pacific equatorial islands. Bernice $P$. Bishop Mus. Bull. 44.

Deenik, J. L., and R. S. Yost. 2006. Chemical properties of atoll soils in the Marshall Islands, and constraints to crop production. Geoderma 136:666-681.

Falkland, A. C., and C. D. Woodroffe. 1997. Geology and hydrogeology of Tarawa and Christmas Island, Kiribati. Pages 577-610 in H. L. Vacher and T. Quinn, eds. Geology and hydrogeology of carbonate islands. Dev. Sedimentol. 54.
Foote, D. E., E. L. Hill, S. Nakamura, and S. Stephens. 1972. Soil survey of the islands of Kauai, Oahu, Maui, Molokai and Lanai, State of Hawaii. Soil Conservation Service, U.S. Department of Agriculture, and University of Hawai'i Agricultural Experiment Station, Washington, D.C.

Fosberg, F. R. 1954. Soils of the northern Marshall atolls with special reference to the Jemo series. Soil Sci. 73:99-107.

Fosberg, F. R., and D. Carroll. 1965. Terrestrial sediments and soils of the northern Marshall Islands. Atoll Res. Bull. 113:159.

Frew, R. D., and K. A. Hunter. 1995. Cadmium-phosphorus cycling at the subtropical convergence south of New Zealand. Mar. Chem. 51:223-237.

Hammond, L. L. 1969. The characterization and classification of the soils of Xmas Island. M.S. thesis, University of Hawai'i at Manoa, Honolulu.

Jenkin, R. N., and M. A. Foale. 1968. An investigation of the coconut-growing potential of Christmas Island. 2 vols. Land Resource Study No. 4, Land Resources Division, Directorate of Overseas Surveys, Tolworth, Surrey, United Kingdom.

Lee, G. W., U. Singh, and R. J. Morrison. 1982. The determination of organic carbon in South Pacific soils. South Pac. J. Nat. Sci. 4:34-42.

Morrison, R. J. 1990. Pacific atoll soils: Chemistry, mineralogy and classification. Atoll Res. Bull. 339:1-25.

1992. Physical and chemical limitations to increased agricultural production on atoll soils. Pages 27-36 in R. C. Chase, ed. Review of agricultural development in the atolls. University of the South Pacific, Apia.

Morrison, R. J., and H. I. Manner. 2005. Premining pattern of soils on Nauru, central Pacific. Pac. Sci. 59:523-540.

Morrison, R. J., and V. B. Seru. 1985. Soils of Abatao Islet, Tarawa, Kiribati. INR Environmental Studies Report No. 27, University of the South Pacific, Suva.

Saenger, C., M. Miller, R. H. Smittenberg, and J. P. Sachs. 2006. A physico-chemical survey of inland lakes and saline ponds: Christmas (Kiritimati) and Washington 
(Teraina) Islands, Republic of Kiribati. Saline Sys. 2:8 doi:10.1186/1746-1448-28.

Samadi, A., and R. J. Gilkes. 1998. Forms of phosphorus in virgin and fertilised soils of Western Australia. Austr. J. Soil Res. 36:585-601.

Schlanger, S. O., M. O. Garcia, B. H. Keating, J. J. Naughton, W. W. Sager, J. A. Haggerty, and J. A. Philpotts. 1984. Geology and geochronology of the Line Islands. J. Geophys. Res. 89:11261-11272.

Schott, G. 1933. The distribution of rain over the Pacific Ocean. Proc. Pac. Sci. Congr. 1933, 3:1887-1890.

Secretariat of the Pacific Commission. 2005. Web site accessed on 4 December 2007: www.spc.int/prism/Country/KI/Stats/ Census2005/Gen-pdf/GTYAB-1.pdf.

Seru, V. B., and R. J. Morrison. 1985. Two soil sequences from South Tarawa, Kiribati. South Pac. J. Nat. Sci. 7:132-156.

Soil Survey Staff. 1999. Soil taxonomy: A basic system of soil classification for making and interpreting soil surveys. 2nd ed. U.S. Dep. Agric. Agric. Handb. 436.

Stone, E. L., Jr. 1951. The soils of Arno Atoll. Atoll Res. Bull. 5:1-56.

Trichet, J., C. Defarge, J. Tribble, G. Tribble, and F. Sansone. 2001. Christmas Island lagoonal lakes, models for the deposition of carbonate-evaporite-organic laminated sediments. Sediment. Geol. 140:177-189.

Valencia, M. J. 1977. Christmas Island (Pacific Ocean): Reconnaissance geologic observations. Atoll Res. Bull. 197:1-17.

Wentworth, C. K. 1931. Geology of the Pacific equatorial islands. Occas. Pap. Bernice Pauahi Bishop Mus. 9:3-21.

Wester, L. 1985. Checklist of the vascular plants of the northern Line Islands. Atoll Res. Bull. 287:1-38.

Woodroffe, C. D., and R. F. McLean. 1998. Pleistocene morphology and Holocene emergence of Christmas (Kiritimati) Island, Pacific Ocean. Coral Reefs 17:235248.

Woodroffe, C. D., and R. J. Morrison. 2001. Reef-island accretion and soil development on Makin, Kiribati, central Pacific. Catena $44: 245-261$.

\section{Appendix}

Profile Details of Major Soils Studied

\section{Pedon No. KRMT 1}

Classification: Medial-skeletal, carbonatic, isohyperthermic Oxyaquic Ustorthent

Location: Kiritimati, Kiribati; $1^{\circ} 50^{\prime} 27.07^{\prime \prime} \mathrm{N}, 157^{\circ} 22^{\prime}$ $00.90^{\prime \prime} \mathrm{W}$; site located close to main cross-island road (Poland Road), about $3.5 \mathrm{~km}$ from main eastcoast road

Physiography: Site located between two isolated lagoons, on top of an old coral terrace, now covered with finer materials; elevation $\pm 2 \mathrm{~m}$ above mean sea level (MSL)

Topography: Flat site; no microrelief; significant areas around site lack vegetative cover; no surface hardpan

Drainage: Site well drained, profile imperfectly drained

Vegetation: Sparse $(<30 \%)$ coverage with Scaevola taccada $(<1 \mathrm{~m})$, Tournefortia argentea $(<1 \mathrm{~m})$, Lepturus repens, Suriana maritima, and few Heliotropium anomalum

Parent material: Coralline lagoon deposits on top of coral platform, including old algal matt material

Climate: Average annual temperature $28^{\circ} \mathrm{C}$; rainfall approximately $914 \mathrm{~mm}$ annually with a slightly wetter period March-July season

Soil profile description:

0-2 cm: dry; thin layer of algal debris, sand, and shells; rubbed color brown (7.5 YR 5/4); structureless; loose; no roots; straight distinct boundary

2-6 cm: accumulated layer of shells, approximately $1-1.5 \mathrm{~cm}$ longest diameter; some strong brown (7.5YR 5/6) sand $(<10 \%)$ mixed with the shells; structureless; loose; few fine roots; straight diffuse boundary

$6-16 \mathrm{~cm}$ : slightly moist; gravelly and stony reddish yellow (7.5 YR 7/6) sand; structureless; loose; very few roots; contact on large broken coral pieces with sand in interstices

Pedon No. KRMT 12 was similar except that it had a coarser texture in the upper sections

\section{Pedon No. KRMT 4}

Classification: Carbonatic, isohyperthermic Typic Psammaqent

Location: Kiritimati, Kiribati; $2^{\circ} 01^{\prime} 26.50^{\prime \prime} \mathrm{N}, 157^{\circ} 25^{\prime}$ $41.23^{\prime \prime} \mathrm{W}$; on north-south track, $0.35 \mathrm{~km}$ north of back road from London to Banana

Physiography: Site in southern section of central ridge of north arm of island, close to lagoon flat area; \pm 2 m above MSL

Topography: Flat site; little microtopography

Drainage: Site excessively well drained; profile somewhat imperfectly drained

Vegetation: Coconut plantation (relatively healthy looking); few Lepturus repens tufts

Parent material: Coral sand, gravels, and some shell material

Climate: Average annual temperature $28^{\circ} \mathrm{C}$; rainfall approximately $914 \mathrm{~mm}$ annually with a slightly wetter period March-July season 
Soil profile description:

$0-1 \mathrm{~cm}$ : dry; layer of coarse sand and gravel-sized coralline algal remains

1-7 cm: slightly moist; very pale brown (10YR 7/3) fine sand; structureless; loose; common medium and fine roots; boundary abrupt to pan, indistinct in zones where pan is absent

$7-8 \mathrm{~cm}$ : discontinuous pan of algal cemented sand, pieces up to $20 \mathrm{~cm}$ maximum diameter

8-18 cm: moist; very pale brown (10YR 8/4) slightly gravelly medium fine sand; structureless; loose; few medium roots; indistinct straight boundary

18-36 cm: wet; very pale brown (10YR 8/4) medium fine sand; structureless; loose; no roots

$36 \mathrm{~cm}$ : water table

Pedon No. KRMT 5 was similar to this profile, except the water table was encountered at greater depth $(83 \mathrm{~cm})$, hence a different classification

\section{Pedon No. KRMT 6}

Classification: Carbonatic, isohyperthermic Aridic Ustipsamment

Location: Kiritimati, Kiribati; $2^{\circ} 00^{\prime} 38.00^{\prime \prime} \mathrm{N}, 157^{\circ} 24^{\prime}$ $10.49^{\prime \prime} \mathrm{W}$; north side of dune approximately $1 \mathrm{~km}$ west of Captain Cook Hotel

Physiography: North side of coastal dune approximately $3 \mathrm{~m}$ high; site $\pm 2 \mathrm{~m}$ above MSL

Topography: Midslope of north side of dune; slope angle of site approximately $8^{\circ}$; slope generally flat, little microtopography

Drainage: Site and profile excessively well drained

Vegetation: Scaevola taccada with Lepturus repens and a few Suriana maritima

Parent material: Coral sand

Climate: Average annual temperature $28^{\circ} \mathrm{C}$; rainfall approximately $914 \mathrm{~mm}$ annually with a slightly wetter period March-July season

Soil profile description:

A, 0-12 cm: dry; pale grayish brown (10YR 6/2-7/2) medium fine sand; structureless; loose; common medium and fine roots; distinct slightly wavy boundary

C, 12-110 cm: dry; pinkish white (7.5YR 8/2) medium fine sand; structureless; loose; no roots; no stones

Pedon No. KRMT 10 was similar to this profile, apart from being at a slightly high elevation

\section{Pedon No. KRMT 8}

Classification: Carbonatic, isohyperthermic Typic Ustipsamment

Location: Kiritimati, Kiribati; $2^{\circ} 02^{\prime} 36.58^{\prime \prime} \mathrm{N}, 157^{\circ} 27^{\prime}$ $40.37^{\prime \prime} \mathrm{W}$; about $100 \mathrm{~m}$ south of main road along north arm of island, near Cape Manning

Physiography: Site located in flat central part of northern arm of island; elevation $\pm 3 \mathrm{~m}$ above MSL

Topography: Flat site, little microtopography

Drainage: Site and profile excessively well drained

Vegetation: Lepturus repens grassland with some coconuts, some in patches, others isolated; isolated Tournefortia argentea

Parent material: Coral sand, gravel, rocks, and other reefderived material

Climate: Average annual temperature $28^{\circ} \mathrm{C}$; rainfall approximately $914 \mathrm{~mm}$ annually with a slightly wetter period March-July season

Soil profile description:

A, 0-17 cm: dry; pale brown (10YR 6/3) fine sand; structureless; loose; common fine and few medium roots; some subangular gravels up to $6 \mathrm{~cm}$ maximum diameter; straight boundary

AC, $17-30 \mathrm{~cm}$ : dry; coral stones (up to $12 \mathrm{~cm}$ maximum diameter) and gravel with pale brown $(10 Y R$ 6/3) fine sand in interstices; common medium roots, many horizontal at bottom of this layer; distinct slightly wavy boundary

C, 30-125 cm: dry; pink (7.5YR 8/3) and pinkish white (7.5YR 8/2) fine sand; structureless; loose; very few stones or gravels; very few medium roots; augering showed water table $>1.5 \mathrm{~m}$; no sample taken for $17-30 \mathrm{~cm}$ layer; unusual rooting pattern with soil eroding away from below coarse layer and roots

Pedon Nos. KRMT 7 and 9 were similar to this one except that they had fewer stones in the middle sections of the profile

\section{Pedon No. KRMT 11}

Classification: Sandy-skeletal, carbonatic, isohyperthermic Typic Ustorthent

Location: Kiritimati, Kiribati; site 100 m north of Korean wreck site on south side of Southeast Point

Physiography: Coastal plain site, set back from beach rampart; site located under Tournefortia argentea (about 5-6 $\mathrm{m}$ high and $15 \mathrm{~m}$ diameter); elevation \pm 2 $\mathrm{m}$ above MSL

Topography: Site flat with no microtopography

Drainage: Site and profile excessively well drained

Vegetation: Tournefortia argentea tree, partially overgrown with Cassytha filiformis, in middle of Lepturus repens grassland

Parent material: Coral sand

Climate: Average annual temperature $28^{\circ} \mathrm{C}$; rainfall approximately $914 \mathrm{~mm}$ annually with a slightly wetter period March-July season

Soil profile description:

$1-0 \mathrm{~cm}$ : thin layer of leaf litter, partially decomposed, plus some windblown fine white sand

A, 0-15 cm: dry; brown (7.5YR 5/2) medium fine sand; structureless; no stones; common fine roots, few medium roots; distinct uneven boundary

C, 15-60 cm: coralline rubble (subrounded stones, rocks) with pale brown (7.5YR 6/2) sand in interstices; structureless; few medium and fine roots

\section{Pedon No. KRMT 14}

Classification: Carbonatic, isohyperthermic Typic Ustipsamment 
Location: Kiritimati, Kiribati; $1^{\circ} 50^{\prime} 49.22^{\prime \prime} \mathrm{N}, 157^{\circ} 28^{\prime}$ 29.11" W; east of Poland near Cecile Peninsula

Physiography: Central ridge site, similar to central part of northern arm of island; elevation $\pm 2.5 \mathrm{~m}$ above MSL

Topography: Flat site, little microtopography, apart from activities associated with coconut planting

Drainage: Site and profile excessively well drained

Vegetation: Lepturus repens grasslands, with occasional Scaevola taccada patches, into which coconuts have been planted (many showing poor discard of fronds associated with salinity problems)

Parent material: Coral sand and gravel

Climate: Average annual temperature $28^{\circ} \mathrm{C}$; rainfall approximately $914 \mathrm{~mm}$ annually with a slightly wetter period March-July season

Soil profile description:

$1-0 \mathrm{~cm}$ : thin layer of white windblown sand
A, 0-21 cm: dry: very pale brown (10YR 7/3) medium fine sand; structureless; loose; no stones; common fine, few medium roots; few coral gravels; indistinct straight boundary

AC, 21-31 cm: dry; yellowish brown (10YR 5/4) medium fine sand; massive in place, breaking to structureless; firm to loose; few fine roots; few subrounded coral gravels; straight diffuse boundary

C, 31-46 cm: dry; pale brown (10YR 6/3) medium fine sand; compact in place but loose when disturbed; structureless; few roots; few rounded small coral stones and gravels

Pedon Nos. KRMT 3, 13, and 15 are similar to this profile except that KRMT 15 had a coarser texture in the upper sections 
